\title{
IMPLEMENTASI MAL PELAYANAN PUBLIK DI KOTA BEKASI PROVINSI JAWA BARAT
}

\author{
Oleh \\ Petra Hasiholan1, \\ Murtir Jeddawi², Ika Sartika ${ }^{3}$ \\ 1) Ditjen Bina Pembangunan Daerah Kementerian Dalam Negeri \\ Program Magister Terapan Studi Pemerintahan Daerah Institut Pemerintahan Dalam Negeri \\ petra.hasiholan@gmail.com \\ 2,3) Institut Pemerintahan Dalam Negeri
}

\begin{abstract}
The implementation of good governance in Indonesia is marked by the realization of quality public services to the community. Public services are the responsibility of the government to realize prosperity in order to achieve goals, therefore researchers are interested in conducting research under the title Implementation of Public Service Mall in the City of Bekasi in North Java Province. This research is focused on knowing and analyzing the Implementation of Public Service Malls in improving the quality of public services.

The research method used is descriptive research with a qualitative informan approach determined by purposive sampling and snowball sampling techniques.Data collection techniques carried out by observation interviews and documentation of data analysis techniques by means of data reduction, data presentation and conclusion drawing, verification.

The results showed that the implementation of services was not optimal due to weaknesses in the dimentions of productivity, linearity, and efficiency. The factors influencing the implementers' inconsistencies with regard to the contents of the policy, not yet optimal network interactions, lack of adequate budgets, not yet maximal competency of employees, and not yet optimal facilities and infrastructure. Efforts are made in addition to the budget, developing the quality of human resources related to increasing competence and developing an online system to support the quality of service.
\end{abstract}

Keywords: implementation, service, service quality

\begin{abstract}
Abstrak
Denyelenggaraan tata kelola pemerintahan yang baik di Indonesia ditandai dengan terwujudnya pelayanan publik kepada masyarakat yang berkualitas. Pelayanan publik menjadi tanggung jawab pemerintah untuk mewujudkan kesejahteraan dalam rangka mencapai tujuan oleh karena itu peneliti tertarik untuk melakukan penelitian dengan judul Implementasi Mal Pelayanan Publik di Kota Bekasi Provinsi Jawa Barat Provinsi Jawa Barat. penelitian ini difokuskan untuk mengetahui dan menganalisis Implementasi Mal Pelayanan Publik dalam meningkatkan kualitas pelayanan publik.
\end{abstract}

Metode penelitian yang digunakan adalah penelitian deskriptif dengan pendekatan kualitatif informan ditentukan dengan teknik purposive Sampling dan Snowball Sampling. 
Teknik pengumpulan data dilakukan dengan wawancara observasi dan dokumentasi teknik analisis data dengan cara reduksi data, penyajian data,verifikasi dan penarikan simpulan.

Hasil penelitian menunjukkan bahwa pelaksanaan pelayanan belum optimal disebabkan oleh kelemahan dalam dimensi produktivitas, linearitas, dan efisiensi. Adapun faktor-faktor yang memengaruhi belum konsistennya para implementor terhadap isi kebijakan, belum optimal interaksi jejaring kerja, kurang memadai anggaran, belum maksimalnya kompetensi pegawai, dan belum optimalnya sarana dan prasarana. Upaya yang dilakukan penambahan anggaran, pengembangan kualitas sumber daya manusia terkait peningkatan kompetensi serta mengembangkan sistem online untuk menunjang adanya kualitas pelayanan.

Kata kunci: implementasi, pelayanan, kualitas pelayanan

\section{PENDAHULUAN}

enyelenggaraan tata kelola

P pemerintahan yang baik di Indonesia ditandai dengan terwujudnya pelayanan publik kepada masyarakat yang berkualitas. Pelayanan publik menjadi tanggung jawab pemerintah untuk mewujudkan kesejahteraan dalam rangka mencapai tujuan. Hal ini sesuai dengan yang diamanatkan dalam pembukaan

Undang-Undang Dasar 1945.

Dengan adanya otonomi daerah, pemerintah daerah memiliki kewenangan untuk mengurusi urusan lokal sehingga masyarakat lebih mudah mendapatkan pelayanan yang maksimal yang bersifat administrasi. Sejalan dengan tujuan otonomi daerah tersebut untuk meningkatkan pelayanan kepada masyarakat melalui Keputusan Menteri Pendayagunaan

Aparatur Negara Nomor 63 Tahun 2003 tentang Pedoman Umum Penyelenggaraan Pelayanan Publik, pemerintah dituntut untuk mengatur tata cara pelaksanaan tugas dan fungsi pelayanan publik di wilayah masingmasing.

Pelayanan itu sendiri disediakan oleh berbagai lembaga dan institusi pemerintahan dengan aparatur pemerintah sebagai pemberi layanan secara langsung kepada masyarakat. Hal tersebut sejalan dengan pendapat Rasyid (2007:43) bahwa:

Terdapat tiga fungsi-fungsi pemerintahan yang hakiki, yaitu pelayanan (servis), pemberdayaan (empowerment) dan pembangunan (development). Pelayanan akan membuahkan keadilan dalam masyarakat, pemberdayaan akan mendorong kemandirian masyarakat dan pembangunan akan meningkatkan kesejahteraan masyarakat.

Perkembangan ilmu pengetahuan dan teknologi saat ini memberikan dampak yang besar sehingga menuntut perubahan pada berbagai sektor, termasuk urusan pemerintahan. Perubahan tersebut juga mengharuskan pemerintah untuk terus melakukan pembenahan dengan tujuan tercapainya peningkatan produktivitas, dan peningkatan pelayanan.

Pemerintah Kota Bekasi pada saat ini tengah berusaha mewujudkan penyelenggaraan pelayanan publik yang cepat, mudah, terjangkau, aman dan dan nyaman juga terintegrasi dengan seluruh jenis pelayanan kementerian/lembaga/ pemerintah daerah/badan usaha milik negara/badan usaha milik daerah/swasta pada satu tempat melalui konsep Mal Pelayanan Publik (MPP) searah dengan Peraturan Menteri Pendayagunaan

Aparatur Negara dan Reformasi Birokrasi Republik Indonesia Nomor 23 Tahun 2017 tentang Penyelenggaraan Mal Pelayanan Publik.

Konsep MPP ditawarkan sebagai solusi dan pelayanan terpadu yang saat ini belum terintegrasi antara pelayanan pusat dan daerah sekaligus pelayanan bisnis dalam satu 
tempat. Sebagaimana konsep Mal di mana kita hanya datang ke satu tempat untuk memenuhi semua keperluan kita, maka konsep MPP Kota Bekasi pada

\section{dibawah:}

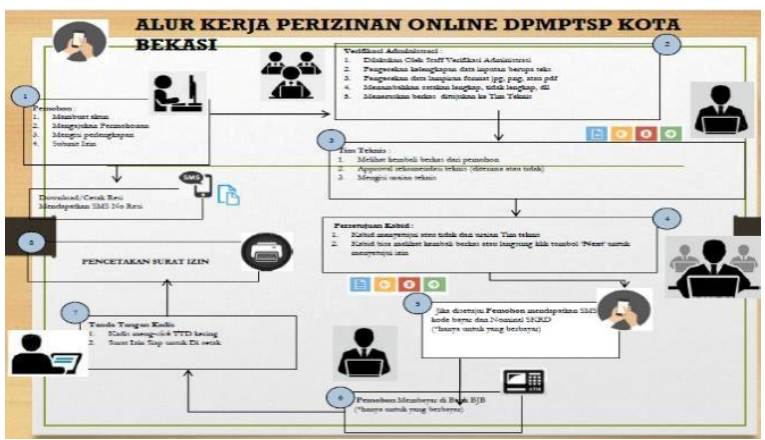

implementasinya adalah mengintegrasikan pelayanan publik yang ada di perkantoran disatukan dalam Mal sebagai tempat masyarakat mendapatkan kebutuhan keperluan sehari-hari.

Dalam pelaksanaan pemberian pelayanan hal yang paling penting diperhatikan adalah alur dari Dinas Penanaman Modal dan Pelayanan Terpadu Satu Pintu (DPMPTSP), Hal ini dapat dilihat pada gambar di bawah:

\section{Gambar 1}

Alur kerja perizinan online DPMPTSP Kota Bekasi

Masalah sumber daya manusia yang masih belum mencukupi dalam pemberian proses pelayanan kepada masyarakat. Hal ini menjadi hambatan dalam aktivitas pelayanan karena kekurangan tenaga kerja untuk memberikan pelayanan pada masyarakat dan hal ini berdampak pada terhambatnya pembuatan administrasi warga seperti masih kurangnya operator jaringan dan sebagainya. Ada beberapa permasalahan dalam penerapan teknologi dan informasi seperti belum tersedianya monitor informasi dan antrean untuk mengurutkan kartu antrean
Dalam proses pelayanan yang diberikan masyarakat.

Masalah selanjutnya adalah sound system (pengeras suara). Karena dalam proses pelayanannya Mal Pelayanan publik sangat ramai dan bergemuruh sehingga panggilan tanpa ada pengeras suara oleh para resepsionis tidak dapat didengar secara jelas. serta masih menggunakan metode pemanggilan manual kepada seluruh masyarakat, sehingga mengurangi efektivitas pelaksanaan pelayanan kepada masyarakat. Kekosongan blanko kartu tanda penduduk elektronik (E-KTP) di Mal Pelayanan Publik menjadi masalah yang dikeluhkan masyarakat. Karena mengantre cukup lama dari pagi hingga sore hari hingga akhirnya masyarakat tidak mendapatkan pelayanan karena blanko terbatas. Misal pada Jumat

(5/10/2018), yaitu sebanyak 100 blanko dari Disdukcapil Kota Bekasi padahal jumlah pemohon mencapai 300 orang lebih sehingga mengecewakan masyarakat. Permasalahan yang terkait dengan prosedur operasional pelayanan perizinan dan penanaman modal, di antaranya cakupan layanan belum lengkap (penolakan, pembatalan, dan pembekuan izin) dan perlu diperjelas izin dan non izin apa saja yang perlu/tidaknya ada rekomendasi teknis.

Prosedur masih perlu distandarisasi, dipersingkat/disederhanakan dan dapat diotomatiskan melalui teknologi informasi untuk mempermudah tata kelola proses perizinan dan perlu ada pendelegasian wewenang penandatanganan izin sesuai kondisi dalam rangka peningkatan pelayanan perizinan (kecepatan dan volume pelayanan). Antrean masyarakat yang cukup panjang dan terbatasnya kuota atau nomor antrean menjadi masalah yang menyebabkan lambatnya aktivitas mal pelayanan publik.

\section{Identifikasi Masalah}


Berdasarkan latar belakang di atas, penulis dapat mengidentifikasi beberapa pokok permasalahan sebagai berikut.

1. Kompetensi Sumber daya aparatur pelayanan Perizinan yang belum Optimal;

2. Sinergitas Perangkat Daerah Teknis kurang optimal;

3. Implementasi waktu penyelesaian proses perizinan yang sesuai Standar Operasional dan prosedur belum optimal;

4. Penerapan teknologi informasi di Mal Pelayanan Publik Kota Bekasi.

\section{Pembatasan Masalah}

Pada penelitian ini penulis menyadari adanya berbagai kekurangan dan kelemahan yang dihadapi, baik terhadap waktu maupun pengetahuan dalam materi. Maka dari itu penulis membatasi pada proses Mal Pelayanan Publik di Kota Bekasi.

\section{Perumusan Masalah}

1. Bagaimana implementasi kebijakan Mal Pelayanan Publik di Kota Bekasi.

2. Faktor apa saja yang menghambat implementasi kebijakan Mal Pelayanan Publik di Kota Bekasi.

3. Upaya apa yang dilakukan untuk mengatasi persoalan dalam proses implementasi kebijakan Mal Pelayanan Publik di Kota Bekasi.

\section{Maksud dan Tujuan Masalah}

Penelitian ini dimaksudkan untuk mendeskripsikan bagaimana implementasi kebijakan Mal Pelayanan Publik di Kota

Bekasi. Adapun tujuan penelitian adalah sebagai berikut.
1. Untuk mengetahui dan menganalisis bagaimana implementasi kebijakan Mal Pelayanan Publik di Kota Bekasi.

2. Untuk mengetahui dan menganalisis faktor faktor apa saja yang menjadi hambatan dalam implementasi Mal

Pelayanan Publik di Kota Bekasi.

3. Untuk mengetahui dan menganalisis upaya apa saja yang dilakukan dalam mengatasi persoalan implementasi Mal Pelayanan Publik di Kota Bekasi.

\section{KAJIAN PUSTAKA}

\section{Asas Penyelenggaraan Pelayanan Publik}

Untuk meningkatkan mutu pelayanan dan daya saing daerah, melalui UU Nomor 23 Tahun 2014 tentang Pemerintah Daerah, pemerintah berupaya untuk mendorong lebih terciptanya daya guna dan hasil guna penyelenggaraan pemerintah daerah dalam menyejahterakan masyarakat, baik melalui peningkatan pelayanan publik maupun daya saing daerah.

Esensi pelayanan publik sesuai UU Nomor 23 Tahun 2014 tentang Pemerintah Daerah berdasarkan Pasal 344 (asas penyelenggaraan) menyebutkan "Pemerintah daerah wajib menjamin terselenggaranya pelayanan publik berdasarkan urusan pemerintahan yang menjadi kewenangan daerah".

\section{Implementasi Kebijakan}

Implementasi kebijakan merupakan salah satu tahap yang sangat penting dalam suatu kebijakan di mana kebijakan harus diterapkan atau diimplementasikan agar mempunyai dampak dan tujuan yang diinginkan sesuai dengan kebijakan yang dibuat. Implementasi adalah suatu tindakan, pelaksanaan, ataupun penerapan dari sebuah 
rencana yang telah disusun secara teratur, matang, dan terperinci. Secara sederhana implementasi dapat diartikan sebagai pelaksanaan ataupun penerapan.

Pemerintah memiliki kewenangan untuk mengambil tindakan ataupun yang menyangkut kepentingan orang banyak, inilah yang disebut kebijakan publik.

Sebagaimana dikemukakan Hamdi (2008: 12) bahwa "Kebijakan publik merupakan produk dari proses penyelenggaraan pemerintahan yang juga merupakan model pilihan tindakan yang akan menentukan nasib warga negaranya semata-mata hanya untuk hubungan melayani dan dilayani".

Van Meter dan Van Horn dan Agustian (2008: 139) menyatakan bahwa "implementasi kebijakan merupakan tindakan-tindakan yang dilakukan baik oleh individu-individu atau pejabat-pejabat atau kelompok-kelompok pemerintah atau swasta yang diarahkan pada tercapainya tujuan-tujuan yang digariskan dalam keputusan kebijaksanaan".

Berdasarkan penjelasan di atas dapat diketahui bahwa implementasi kebijakan menyangkut tiga hal, yaitu (1) adanya tujuan atau sasaran kebijakan; (2) adanya aktivitas atau kegiatan pencapaian tujuan; dan (3) adanya hasil. Berdasarkan uraian tersebut dapat disimpulkan bahwa implementasi merupakan suatu proses yang dinamis, di mana pelaksanaan kebijakan melakukan suatu aktivitas atau kegiatan, sehingga akhirnya mendapatkan suatu hasil yang sesuai dengan tujuan atau sasaran kebijakan itu sendiri.

Konsep implementasi model George C. Edward III (1980) dalam Subarsono (2011: 90) mengatakan bahwa keberhasilan suatu implementasi dipengaruhi oleh empat variabel, yakni (1) komunikasi; (2) sumber daya: (3) disposisi; dan (4) struktural birokrasi di mana keempat variabel tersebut saling berhubungan satu sama lain. Adapun penjelasannya sebagai berikut.

\section{Komunikasi}

Keberhasilan implementasi kebijakan mensyaratkan agar implementor mengetahui apa yang harus dilakukan, apa yang menjadi tujuan dan sasaran kebijakan harus ditransmisikan kepada kelompok sasaran (target group) sehingga akan menguragi distorsi implementasi apabila tujuan dan sasaran suatu kebijakan tidak jelas atau bahkan tidak diketahui sama sekali oleh kelompok sasaran, maka kemungkinan akan terjadi resistensi dari kelompok sasaran.

\section{Sumber daya}

Walaupun isi kebijakan sudah dikomunikasikan secara jelas dan konsisten, tetapi apabila implementor kekurangan sumber daya untuk melaksanakan implementasi maka tidak akan berjalan efektif.

\section{Disposisi}

Watak dan Karakteristik yang dimiliki oleh implementor seperti komitmen, kejujuran dan sifat demokratis. Apabila implementor memiliki disposisi yang baik, maka dia akan dapat menjalankan kebijakan dengan baik seperti yang diinginkan oleh pembuat kebijakan.

\section{Struktur birokrasi}

Bertugas mengimplementasikan kebijakan memiliki pengaruh yang signifikasi terhadap implementasi kebijakan, salah satu dari aspek struktur yang penting dari setiap organisasi adalah adanya prosedur operasi standar (SOP) di mana 
akan menjadi pedoman bagi setiap implementor dalam bertindak.

Sementara itu, kualitas pelayanan adalah segala bentuk aktivitas yang dilakukan oleh perusahaan guna memenuhi harapan konsumen. Pelayanan dalam hal ini diartikan sebagai jasa atau service yang disampaikan oleh pemilik jasa yang berupa kemudahan kecepatan hubungan kemampuan dan keramahtamahan yang ditujukan melalui sikap dan sifat dalam memberikan pelayanan umtuk kepuasan konsumen.

\section{Pelayanan Perizinan}

Keputusan Menteri Pendayagunaan Aparatur Negara Nomor 63 Tahun 2003 mendefinisikan pelayanan piblik sebagai segala bentuk pelayanan yang dilaksanakan oleh Instansi Pemerintah Pusat. Di daerah dan di lingkungan Badan Usaha Milik Negara (BUMN) atau Badan Usaha Milik Daerah (BUMD) dalam bentuk barang dan jasa, baik dalam rangka upaya pemenuhan kebutuhan masyarakat maupun dalam rangka pelaksanaan ketentuan peraturan perundang-undangan.

\section{Teori Pemerintahan}

Menurut W.S. Sayre (1960) pemerintah dalam definisi terbaiknya adalah sebagai organisasi dari negara yang memperlihatkan dan menjalankan kekuasaannya. Pengertian Pemerintah Daerah Pemerintah atau Government dalam bahasa indonesia berarati pengarahan dan administrasi yang berwenang atas kegiatan orang-orang dalam sebuah negara, negara bagian, atau kota dan sebagainya. Bisa juga berarti lembaga atau badan yang menyelenggarakan pemerintahan negara, negara bagian, atau kota, dan sebagainya.

Pemerintah memiliki fungsi di antaranya sebagai berikut.

\section{Fungsi Pelayanan}

Perbedaan pelaksanaan fungsi pelayanan yang dilakukan Pemerintah Pusat dan Pemerintah Daerah terletak pada kewenangan masingmasing. Kewenangan pemerintah pusat mencakup urusan pertahanan keamanan, agama, hubungan luar negeri, moneter dan peradilan. Secara umum pelayanan pemerintah mencakup pelayanan publik (public service) dan pelayanan sipil (civil service) yang menghargai kesetaraan.

\section{Fungsi Pengaturan}

Fungsi ini dilaksanakan pemerintah dengan membuat peraturan perundangundangan untuk mengatur hubungan manusia dalam masyarakat. Pemerintah adalah pihak yang mampu menerapkan peraturan agar kehidupan dapat berjalan secara baik dan dinamis.

\section{Fungsi Pembangunan}

Pemerintah harus berfungsi sebagai pemacu pembangunan di wilayahnya, di mana pembangunan ini mencakup segala aspek kehidupan tidak hanya fisik tapi juga mental spriritual. Pembangunan akan berkurang apabila keadaan masyarakat membaik, artinya masyarakat sejahtera. Jadi, fungsi pembangunan akan lebih dilakukan oleh pemerintah atau Negara berkembang dan terbelakang, sedangkan Negara maju akan melaksanakan fungsi ini seperlunya.

\section{Fungsi Pemberdayaan (Empowerment)}

Fungsi ini untuk mendukung terselenggaranya otonomi daerah, fungsi ini menuntut pemberdayaan Pemerintah 
Daerah. Dalam fungsi ini pemerintah harus memberikan ruang yang cukup bagi aktivitas mandiri masyarakat, sehingga dengan demikian partisipasi masyarakat di Daerah dapat ditingkatkan. Lebih-lebih apabila kepentingan masyarakat diperhatikan, baik dalam peraturan maupun dalam tindakan nyata pemerintah

\section{METODE PENELITIAN}

\section{Desain Penelitian}

Penelitian ini menggunakan penelitian kualitatif. Menurut Cresswell (2013: 4) menyatakan bahwa "penelitian kualitatif merupakan metode metode untuk mengeksplorasi dan memahami makna sejumlah individu atau sekelompok orang, dianggap berasal dari masalah sosial atau kemanusiaan".

Mulyadi (2014:97) mengatakan bahwa "Metode kualitatif, yaitu aktivitas merancang untuk mendapatkan deskripsi, gambaran atau lukisan secara sistematik, faktual dan akurat mengenai fakta fakta, sifat sifat serta hubungan antar fenomena yang diselidiki".

Dengan menggunakan penelitian kualitatif dalam penelitian ini diharapkan dapat memberikan gambaran atas masalah yang menghambat implementasi Mal Pelayanan Publik serta dapat merumuskan berbagai solusi yang dapat ditempuh untuk menyelesaikan masalah dalam implementasi kebijakan Mal Pelayanan Publik (MPP) di Kota Bekasi.

\section{Kerangka Konseptual Penelitian}

Penelitian ini menggunakan metode deskriptif dengan pendekatan kualitatif. Metode ini untuk menggambarkan apa adanya mengenai suatu variabel, gejala keadaan atau fenomena sosial tertentu.
Fokus dalam penelitian ini adalah variabel implementasi kebijakan diukur berdasarkan dimensi implementasi kebijakan menurut Hamdi (2014: 105), yaitu "produktivitas, linearitas, efisiensi". Kemudian untuk melihat faktor yang memengaruhi implementasi kebijakan Mal Pelayanan Publik. Peneliti mengacu pada teori Hamdi (2014: 106), yaitu "substansi kebijakan, perilaku tugas pelaksana, interaksi jejaring kerja, partisipasi kelompok sasaran, sumber daya".

\section{Teknik dan Instrumen Pengumpulan Data}

Sumber data utama penelitian kualitatif ialah melalui kata dan tindakan, maka teknik yang digunakan wawancara, observasi, dan dokumentasi guna memperoleh data yang dibutuhkan sesuai dengan permasalahan yang diteliti.

\section{HASIL PENELITIAN DAN PEMBAHASAN}

\section{Gambaran Umum Lokasi Penelitian}

Secara geografis Kota Bekasi merupakan daerah perbatasan antara Provinsi Jawa Barat dan Provinsi DKI Jakarta, sekaligus merupakan bagian dari perlintasan atau poros Sumatera - Jakarta - Jawa Tengah Jawa Timur maupun poros Jakarta Bandung. Secara administratif Kota Bekasi dibagi menjadi 12 wilayah kecamatan, yaitu: Medansatria, Bekasi Utara, Bekasi Barat, Bekasi Selatan, Bekasi Timur,

Rawalumbu, Pondokgede, Jati Asih, Pondokmelati, Mustikajaya, Bantargebang, dan Jatisampurna. Kecamatan Mustika Jaya mempunyai wilayah yang paling luas, yaitu

24,7 km2, sedangkan Kecamatan Bekasi Timur merupakan wilayah yang paling kecil, yaitu $13,5 \mathrm{~km} 2$. Dari 12 kecamatan, terbagi lagi menjadi 56 kelurahan, di mana setiap kecamatan dibagi sedikitnya menjadi 4 
kelurahan. Pusat Kota Bekasi berada pada Kecamatan Bekasi Timur.

Aktivitas pemerintahan kemasyarakatan di Kota Bekasi pada awal pembentukannya, secara administratif dibagi menjadi 12 kecamatan dengan 56 kelurahan dan tidak memiliki desa .Dinamika pembangunan yang terjadi akibat pelaksanaan secara sinergis antara Pemerintah daerah dan masyarakat telah membawa dampak perubahan yang ditandai perkembangan dan kemajuan di berbagai bidang.

\section{Implementasi Kebijakan Mal Pelayanan Publik di Kota Bekasi}

Tujuan utama penyelenggaraan pelayanan publik adalah meningkatkan kesejahteraan masyarakat. Pelayanan publik yang diberikan oleh aparat pemerintah dalam suatu birokrasi pemerintah sudah menjadi persoalan secara nasional bahwa citranya masih sangat buruk hingga saat ini. Namun hal ini tidak menjadikan alasan utama untuk tidak merubah atau memperbaiki model pelayanan yang diberikan untuk menjadi lebih baik. Paradigma pelayanan yang selama ini menempatkan aparatur dengan birokrasinya pada posisi yang harus dilayani, tetapi harus berubah kepada paradigma yang menempatkan penggunaan jasa pada posisi yang lebih tinggi.

Untuk mengetahui bahwa Mal Pelayanan Publik Kota Bekasi sudah optimal dalam menjalankan pemberian pelayanan di Kota Bekasi kepada masyarakat. Oleh Karena itu, dalam Penelitian ini peneliti menggunakan indikator implementasi kebijakan yang di kemukakan oleh Hamdi (2014: 105), yaitu produktivitas, linearitas, dan efisiensi.

\section{Produktivitas}

Produktivitas merupakan kemampuan organisasi untuk memproduksi jumlah dan mutu output yang sesuai sasaran dengan permintaan lingkungan. Hal ini meliputi proses kerja, hasil kerja, kualitas kerja, kuantitas kerja, dan waktu produksi. Ukuran tentang produksi berhubungan secara langsung dengan keluaran yang dikonsumsi oleh pelanggan organisasi. Kaitannya dengan Pelayanan, yaitu seberapa banyak dokumen yang dikeluarkan dan kualitasnya baik.

Tabel 1

Data Rekapitulasi Blanko E-KTP di Mal Pelayanan Publik Kota Bekasi

\begin{tabular}{|c|c|c|c|}
\hline No. & Hari/Tangal & Blanko & Pemohon \\
\hline 1 & Selasa, 22 Juli 2019 & 200 & 359 \\
\hline 2 & Rabu, 23 Juli 2019 & 250 & 286 \\
\hline 3 & Kamis, 24 Juli 2019 & 200 & 302 \\
\hline
\end{tabular}

Sumber: Mal Pelayanan Publik Kota Bekasi

Berdasarkan tabel di atas dapat dijelaskan, bahwa proses pembuatan e-KTP di Mal Pelayanan Publik telah berjalan dengan baik namun masih terdapat keterbatasan blanko, jumlah blanko yang dikeluarkan oleh Mal Pelayanan Publik Kota Bekasi.

\section{Linearitas}

Linearitas merupakan kesesuaian proses pemenuhan standar dengan pedoman spesifikasi standar yang telah ditentukan. Kesesuaian tersebut menyangkut prosedur, waktu, biaya, tempat, dan pelaksana.

\section{Standar Operasional Prosedur (SOP)}

Dalam penelitian proses penyelesaian pelayanan masih mengalami hambatan, karena belum terintegrasinya beberapa 
instansi untuk memberikan proses pelayanan. selain itu observasi penulis di lapangan yang menunjukkan memang terkait prosedur operasional pelayanan pada Mal Pelayanan Publik Kota Bekasi masih terdapat kendala.

\section{Waktu Pelaksanaan Pelayanan}

Kejelasan waktu tentu menjadi hal pokok untuk penilaian pelayanan dari Mal Pelayanan Publik Kota Bekasi terhadap masyarakat yang dilayani.

Berdasarkan wawancara penulis dengan kordinator mal pelayanan publik pada

24 Agustus 2019 yang mengatakan bahwa:

Kalau secara umum pelayanan di MPP maupun GPP itu sudah sesuai dengan SPK. Contohnya perpanjangan sim, itu tinggal foto dan menunggu, langsung terbit hari itu juga. Kemudian SKCK baru maupun perpanjang, langsung dia foto di situ, cap tiga jari, itu langsung bisa diakses ataupun langsung dicetak oleh petugas dari polres. Untuk pelayanan perizinan dari DPMPTSP itu sudah bisa diakses karena sifat dari pelayanan MPP dan GPP itu adalah online. SOCK,

IMTA, IPTM, SIP Dokter, Surat Izin Usaha Perdagangan, dan Tanda Daftar Perusahaan, itu semua sudah online dan pelayanannya sifatnya hari itu juga jadi. Di tempat yang sama penulis melakukan wawancara dengan Haryati Martina pada 24 Agustus 2019, bahwa:

Memang benar ada beberapa pelayanan yang sifatnya hari itu juga jadi. salah satunya seperti surat izin SIP dokter atau perpanjangan SIM. Namun tidak dipungkiri juga yang sering menjadi keluhan bagi warga itu terkait pembuatan e-KTP selalu mengalami ketidakpastian waktu.

\section{Biaya Pelayanan}

Pelayanan merupakan sekumpulan biaya yang dikeluarkan masyarakat untuk mendapatkan produk layanan atau jasa.

Berdasarkan hasil wawancara dengan kordinator Mal Pelayanan Publik pada

22 Agustus 2019 yang menyatakan, bahwa:

Bisa dikatakan seluruh pelayanan hampir gratis. Kalau kita katakan hampir, masih ada pemasukan daerah yang harus dibayar misalnya pajak BPNKB, SIM itu ada PNBP, itu setoran sah. Kemudian

IMTA itu ada retribusinya. tetapi secara umum sudah free hanya sebagian yang ada setoran resmi.

Berdasarkan wawancara di atas, bahwa dari segi biaya, memang ada yang tidak dibayar seperti pembuatan e-KTP dan Akta Kelahiran yang sudah dianggarkan oleh instansi tersebut. Namun ada juga yang berbayar seperti pembuatan

SIM, SIUP dan surat izin yang memiliki setoran dan pajak resmi dikeluarkan untuk masuk ke kas Daerah.

\section{Fasilitas}

Fasilitas juga merupakan salah satu pendukung dalam proses implementasi. Kekurangan fasilitas akan berdampak pada pencapaian tujuan dari kebijakan tidak maksimal.

Berdasarkan observasi penulis, kondisi sarana dan prasarana sudah cukup baik namun masih terdapat kekurangan seperti tidak adanya pengeras suara yang digunakan untuk memanggil nomor antrean. 


\section{Sosialisasi DPMPTSP kepada Masyarakat Kota Bekasi}

Komunikasi pertama yang diharapkan dari penelitian ini adalah sosialisasi pelaksanaan kebijakan pelayanan perizinan pada Mal Pelayanan Publik Kota Bekasi terhadap masyarakat yang didukung peran aktif pegawai Mal Pelayanan Publik Kota Bekasi untuk jalannya kegiatan pelayanan yang baik dan lancar.

\section{Efisiensi}

Secara ideal, pelayanan akan efisiensi apabila birokrasi pelayanan dapat menyediakan input pelayanan, kemampuan pendayagunaan sumber daya yang meringankan masyarakat sebagai pengguna jasa, terutama dalam mendapatkan pelayanan perizinan dan non perizinan pada Mal Pelayanan Publik Kota Bekasi. Demikian pula pada sisi output pelayanan, birokrasi secara ideal dapat memberikan produk pelayanan yang berkualitas, terutama dari aspek ketepatan pelayanan.

\section{Sikap dan Perilaku}

Berdasarkan observasi peneliti, pegawai Mal Pelayanan Publik Kota Bekasi tingkat loyalitas kepada atasan cukup terlihat baik. Pegawai di kantor ini cukup ramah dalam melayani masyarakat, saya senang mengurus izin di sini. Ketika saya belum memahami tentang kelengkapan dokumen petugas juga menjelaskannya dengan baik, sopan dan cukup ramah.

Selanjutnya berdasarkan pengamatan peneliti, sikap pegawai mal pelayanan publik sudah cukup baik dalam melayani masyarakat. terlihat dari cara mereka berbicara, cara berpakaian dan sikap mereka, bahkan wawancara penulis kepada koordinator Mal Pelayanan
Publik yang mengatakan memang mereka sudah melakukan diklat pelayanan.

\section{Kompetensi Pegawai}

Kompetensi pegawai merupakan salah satu faktor pendukung dalam Implementasi Kebijakan Pelayanan

Perizinan dan non perizinan pada mal pelayanan publik Kota Bekasi. diklat peningkatan Kompetensi sudah terlaksana, namun belum semua pegawai yang secara teknis menangani pelayanan langsung pada masyarakat. Oleh karena itu, perlu lagi diadakan diklat yang disesuaikan dengan anggaran yang ada agar secara signifikan dan berkelanjutan peningkatan pengetahuan, kemampuan dan skill para pegawai lebih memadai lagi dalam memberikan pelayanan langsung kepada masyarakat.

\section{Anggaran}

Anggaran merupakan sebuah tolak ukur terlaksananya sebuah pelaksanaan penyelenggaraan pelayanan terutama yang di sediakan oleh pemerintah.

Berdasarkan wawancara dan obesrvasi penulis, dapat dikatakan bahwa anggaran DPMPTSP Kota Bekasi mengalami penurunan, hal ini dikarenakan ketersediaan dana di kas daerah tidak memenuhi sehingga terjadi penurunan penyerapan realisasi anggaran pada

2018 sehingga terjadilah tunda bayar berdasarkan Keputusan Wali kota Nomor 900/Kep543/DPMPTSP/XII/2018 pada Dinas Penanaman Modal Satu Pintu Kota Bekasi. 


\section{Teknologi}

Teknologi merupakan salah satu sumber daya pendukung dalam Implementasi Kebijakan Pelayanan Perizinan pada Mal Pelayanan Publik Kota Bekasi.

Berdasarkan wawancara dapat dikatakan bahwa kuantitas teknologi yang digunakan pegawai Mal Pelayanan Publik Kota Bekasi sudah memenuhi kebutuhan pelayanan perizinan masyarakat.

\section{Faktor yang Memengaruhi Implementasi Kebijakan Mal Pelayanan Publik di Kota Bekasi}

Mal Pelayanan Publik Kota Bekasi
melalui visi dan misinya tentu
mengedepankan pelayanan perizinan yang
berkualitas, merupakan pelayanan yang
menjadi keunggulan mal pelayanan publik.
Walaupun dalam prosesnya terdapat
pengaruhpengaruh yang tidak bisa
dihindarkan seperti substansi kebijakan,
perilaku tugas pelaksana, interaksi jejaring
kerja, partisipasi kelompok sasaran, dan
sumber daya dalam melaksanakan pelayanan
publik tersebut.

\section{Substansi Kebijakan}

Substansi kebijakan merupakan isi dari kebijakan DPMPTSP yang berisikan akan konsistensi isi kebijakan atau spesifikasi kebijakan tersebut.

\section{Konsistensi kebijakan}

Konsistensi kebijakan merupakan terkait sikap dan perilaku dalam melaksanakan isi kebijakan pelayanan perizinan yang dibuat berdasarkan tujuan dan kebutuhan masyarakat akan pelayanan. Secara umum dijelaskan bahwa substansi kebijakan dihadapkan pada wewenang, tugas dan tanggung jawab yang diamanatkan melalui kebijakan pelayanan perizinan pada mal pelayanan publik. pada dasarnya pemerintah Kota Bekasi konsisten dalam melaksanakan inovasi, hal ini terlihat dengan akan dibukanya beberapa gerai mal pelayanan publik di Kota Bekasi menjadi tolak ukur konsistensi dalam menciptakan pelayanan yang mudah kepada masyarakat.

\section{Keselarasan isi kebijakan dengan isi kebijakan lain}

Kebijakan MPP bertujuan meningkatkan kualitas pelayanan publik serta memberikan akses yang luas kepada masyarakat untuk memperoleh pelayanan publik.

Wujud dari sebuah kebijakan untuk sebuah sistem pelayanan terpadu di mana proses pengelolaan beberapa jenis pelayanan perizinan dilakukan secara terintegrasi dalam satu tempat. Olehnya kebijakan pelayanan perizinan yang dilaksanakan Mal Pelayanan Publik Kota Bekasi tidak lain untuk memudahkan masyarakat untuk mengurus izin sebagai sasaran kebijakan tersebut.

\section{Perilaku Tugas Pelaksana}

Peningkatan kualitas pelayanan dan menjamin penyediaan pelayanan publik sesuai dengan asas-asas umum pemerintahan merupakan suatu perwujudan untuk memberikan pelayanan prima kepada masyarakat, pelayanan yang diberikan tentu diharapkan dapat memenuhi kebutuhan dan keinginan masyarakat berdasarkan aturan yang berlaku.

Motivasi berkaitan erat dengan insentif yang diberikan, penghargaan atas keberhasilan bekerja, dan hukuman bagi yang melanggar wewenang. 
Motivasi kerja berpengaruh besar terhadap pelayanan yang diberikan. Sesuai teori Jones (1994) yang menjelaskan bahwa pelaksanaan implementasi kebijakan menuntut adanya beberapa syarat, antara lain adanya orang atau pelaksana, uang dan kemampuan operasional, yang dalam hal ini sering disebut resources. Motivasi kerja merupakan salah satu faktor yang memengaruhi kinerja dalam suatu organisasi.

\section{Interaksi Jejaring Kerja}

Keberhasilan sebuah organisasi dalam memberikan pelayanan kepada masyarakat tidak hanya ditentukan oleh organisasi itu sendiri tetapi juga dukungan dari organisasi lain semakin besar dukungan organisasi lain semakin mudah organisasi tersebut meraih keberhasilan.

Kerja sama antarpelaksana sangat memengaruhi produktivitas pelayanan pada Mal Pelayanan Publik, dalam rangka mendukung keberhasilan pelayanan. Hal ini menyangkut seberapa baiknya koordinasi yang dilakukan antarpelaksana dalam melak sanakan program/kegiatan yang sedang dijalankan.

\section{Partisipasi Kelompok Sasaran}

Partisipasi kelompok sasaran merupakan gejala di mana orang dilibatkan dan diikutsertakan dalam pelaksanaan program/kegiatan yang akan dilaksanakan, terkait dengan program yang berhubungan dengan pelayanan perizinan.

Ketika partisipasi masyarakat atau kelompok sasaran meningkat dalam mengikuti kebijakan mal pelayanan publik, untuk mengikuti prosedur pelayanan perizinan.

Berdasarkan hasil wawancara dapat dipahami bahwa kemampuan pegawai dan masyarakat dalam berkontribusi kepada Mal Pelayanan Publik sudah sesuai prosedur dan hal ini patut diapresiasi.

\section{Sumber Daya}

Sumber daya merupakan salah satu faktor pendukung dalam pelaksanaan suatu kebijakan di mana sumber daya terdiri dari dari sumber daya manusia (human resources) dan sumber daya selain manusia (non-human resources) dalam sumber daya pada dasarnya adalah berbicara mengenai kesiapan anggaran, aparatur, sarana dan prasarana yang dimiliki untuk mendukung pelaksanaan kegiatan pelayanan perizinan di Mal Pelayanan Publik.

\section{Kecukupan Anggaran}

Anggaran dan program merupakan satu kesatuan yang menentukan kesuksesan kegiatan berjalan dengan baik dan lancar khususnya pelaksanaan Pelayanan

Perizinan.

Anggaran yang terbatas tentu akan memengaruhi seberapa banyaknya kegiatan yang dapat terlaksana. Terkait hal tersebut, sesuai dengan Pendapat

Tjiptono (2008: 85) bahwa kemampuan anggaran akan memengaruhi kinerja pelayanan kepada masyarakat secara berkualitas.

\section{Ketersediaan Sumber Daya Manusia}

Sumber daya manusia merupakan faktor yang dapat memengaruhi pelaksanaan mal pelayanan publik Kota Bekasi.

\section{Kecukupan Fasilitas Sarana/Prasarana}

Pengembangan Implementasi Kebijakan ini pula tentu harusnya ditunjang oleh 
fasilitas, yaitu sarana dan prasarana pelayanan yang baik, seperti ATK yang lengkap, papan informasi yang jelas, gedung ber- $A C$, Perluasan kantor.

Berdasarkan hasil pengamatan, fasilitas yang ada di Mal Pelayanan Publik Kota Bekasi sudah baik, namun tentu saja saran dan prasarana yang harus tetap dioptimalkan, walaupun secara umum sudah terpenuhi serta tetap perlu ditingkatkan karena memang pada dasarnya masih ada kekurangankekurangan. Berdasarkan penjelasan tersebut bahwasanya ketersediaan sarana dan prasarana yang memadai tentu akan menciptakan pelayanan yang terbaik dan hal ini menjadi tujuan dan harapan masyarakat dan Pemerintah Kota Bekasi

\section{Kecukupan Informasi}

Dalam pelaksanaan pelayanan terpadu satu pintu ini khususnya pelayanan perizinan. Sejalan dengan tujuan otonomi daerah dalam meningkatkan pelayanan kepada masyarakat.

\section{Ketepatan Teknologi}

Perkembangan teknologi informasi yang sangat pesat memberikan banyak kemudahan dalam memberikan pelayanan perizinan kepada masyarakat, peran teknologi dalam kegiatan pelayanan perizinan dapat dipahami sebagai sebuah kebutuhan manajemen perkantoran sebagai sistem informasi dalam mengolah data menjadi sebuah laporan dengan penggunaan komputer, sehingga teknologi informasi dapat memenuhi kebutuhan informasi akan pelayanan perizinan dengan sangat cepat, tepat waktu, relevan, dan akurat.

\section{Upaya yang Dilakukan untuk Mengatasi Persoalan dalam Proses Implementasi Kebijakan Mal Pelayanan Publik di Kota Bekasi}

Untuk dapat meningkatkan Pelaksanaan Kebijakan Pelayanan Perizinan mal pelayanan publik, maka perlu melakukan beberapa hal yang dapat mengatasi permasalahan- permasalahan yang sering terjadi dalam setiap pelaksanaan pelayanan. Hal ini sesuai dengan pendapat Moenir

(2001: 88-127), yaitu pelayanan kepada masyarakat akan terlaksana dengan baik dan memuaskan apabila didukung oleh beberapa faktor antara lain:

1. Kesadaran, adalah hasil dari suatu proses yang terkadang-kadang memerlukan waktu yang cukup lama dan dalam keadaan tenang tidak dalam keadaan emosi. Kesadaran pegawai dalam segala tingkatan terhadap tugas/ pekerjaan yang menjadi tanggung jawabnya membawa dampak yang sangat positif terhadap organisasi dan tugas itu sendiri. Ia akan menjadi sumber kesengguhan dan disiplin dalam mewujudkan standar pelaksanaan maupun standar operasional.

2. Faktor aturan, aturan adalah perangkat penting dalam segala tindakan dan perbuatan orang. Aturan dalam organisasi mutlak keberadaannya agar organisasi dan pekerjaan dalam berjalan teratur dan terarah.

3. Faktor organisasi, organisasi pelayanan merupakan mengorganisir fungsi pelayanan baik dalam bentuk struktur maupun mekanisme yang akan berperan dalam mutu dan kelancaran pelayanan.

4. Faktor pendapatan yang dimaksud pendapatan adalah semua penerimaan dalam bentuk apapun yang diperoleh dari suatu organisasi tempat kerja 
(termasuk fasilitas) yang berkaitan dengan kedudukan dan perannya dalam organisasi kerja tersebut.

Juga sebagai izinalan atas tenaga dan pikiran yang telah dicurahkan pada organisasi.

5. Faktor kemampuan dan keterampilan, merupakan kemampuan dan keterampilan para pegawai dalam melaksanakan tugas baik mereka yang termasuk golongan pimpinan maupun bawahan.

6. Faktor sarana pelayanan, sarana pelayanan adalah segala jenis peraturan, perlengkapan kerja dan fasilitas lainnya yang berungsi sebagai alatutama. Pembantu dalam pelaksanaan pekerjaan dan juga berungsi sosial dalam rangka kepentingan orang-orang yang sedang berhubungan dengan organisasi kerja.

Peningkatan Kualitas Sumber Daya Manusia dalam Memberi Pelayanan

\section{Perizinan pada Mal Pelayanan Publik}

Dalam menjalankan tugas dan fungsinya sebagai pelayan masyarakat, tentunya setiap aparatur pemerintahan harus mempunyai kemampuan yang harus dimiliki oleh masing-masing individu dalam memberikan pelayanan.

Menurut penulis tidak hanya bimbingan secara teknis yang harus dilakukan DPMPTSP Kota Bekasi kepada para pegawai pemberi layanan dalam meningkatkan kualitas aparaturnya, tetapi juga pemberian diklat untuk membentuk sosok pegawai yang mengarah pada:

1. Peningkatan sikap dan semangat pengabdian yang berorientasi kepada kepentingan masyarakat.

2. Peningkatan kompetensi teknis manajerial.
3. Peningkatan semangat kerja dan tanggung jawab sesuai dengan lingkungan kerja dan organisasinya.

Sehubungan dengan pelaksanaan pelayanan yang baik, karakter yang harus ada pada diri seorang pegawai dalam memberi pelayanan, yaitu berkaitan dengan pengetahuan dan keterampilan, memiliki daya kreativitas yang tinggi, meningkatkan disiplin kerja, memahami cara-cara berkomunikasi yang baik, memahami kemauan masyarakat dan dapat mengendalikan emosi saat memberikan pelayanan perizinan kepada masyarakat.

Berdasarkan uraian di atas, maka dalam rangka meningkatkan pelayanan publik dalam mencapai suatu organisasi pemerintahan yang berkualitas, maka suatu organisasi pemerintahan harus selalu berupaya menciptakan peningkatan pengetahuan, keterampilan, dan kemampuan pegawainya dalam meningkatkan kapasitas, kualitas, dedikasi, kontribusi, dan prestasi kerja pegawainya yang prima. Disamping itu diklat juga mampu memberikan terwujudnya sosok aparatur negara yang memiliki jati diri sebagai abdi negara dan masyarakat dengan komitmen, integritas, dan kemampuan profesional yang tinggi dalam mengemban tugas dan tanggung jawab serta memberikan pelayanan yang baik kepada masyarakat.

\section{Mengembangkan Sistem Online dalam Pemberian Pelayanan Publik}

Sistem online diperlukan untuk meningkatkan informasi-informasi terkait pelayanan perizinan DPMPTSP Kota Bekasi . Sistem online ini ke depannya akan sangat berguna bagi masyarakat Kota Bekasi. Sistem ini akan sangat membantu dalam menyediakan informasi terkait pelayanan. 
Dalam suatu organisasi pemerintahan, teknologi informasi sangat dibutuhkan untuk mencapai keunggulan yang kompetitif, organisasi yang memiliki keunggulan adalah organisasi yang memiliki kepaduan secara integral antara manusia dengan sistem kelengkapan informasi sebagai alat penunjang keberhasilan suatu organisasi. Untuk itulah DPMPTSP Kota Bekasi tidak hanya meningkatkan sistem teknologi dari media online saja, tetapi juga akan meningkatkan kualitas pegawainya. Pemberian Pendidikan dan pelatihan akan dilakukan secara bertahap oleh DPMPTSP Kota Bekasi kepada seluruh pegawainya

Kemampuan pegawai dalam menjalankan sistem teknologi juga harus di ditingkatkan mengingat ke depannya

DPMPTSP Kota Bekasi dan dinas-dinas terkait akan meningkatkan media online dalam mengoptimalkan pelayanan mereka kepada masyarakat. Tidak hanya melayani masyarakat di kantor saja tetapi diharapkan agar setiap pegawai yang berada DPMPTSP Kota Bekasi dapat difungsikan sebagai operator serta mampu memprogramkan komputer.

Kehadiran sistem komputerisasi dengan segala sistem software maupun aplikasi yang dimiliki akan sangat membantu DPMPTSP

Kota Bekasi dan dinas-dinas terkait perizinan yang ada di Kota Bekasi untuk dapat meningkatkan kinerja layanan pemerintahan menjadi prima. Pada prinsipnya untuk membangun suatu sistem informasi yang ideal akan membutuhkan cost yang mahal dan dimensi waktu yang relatif panjang untuk penyesuaiannya. Hal ini terutama berkaitan dengan kemampuan daerah dalam beradaptasi. Bagi setiap aparatur pelayanan pun membutuhkan waktu yang panjang dalam melakukan orientasi pekerjaan teknis di bidang pelayanan yang berbasis IT ini. Oleh karena itu, Pemerintah Kota Bekasi harus mempunyai komitmen dan kemauan yang tinggi dalam meningkatkan kualitas aparaturnya dalam rangka menerapkan konsepsi spesialisasi kerja khususnya di bidang pengelolaan data dan informasi yang berbasis online. Karena dengan menempatkan pegawai yang profesional di bidangnya tentunya tujuan pemerintah daerah akan mudah tercapai.

Menurut penulis untuk membangun sistem informasi pelayanan perizinan dengan sistem online, Mal Pelayanan Publik harus memperhatikan beberapa syarat penting sehubungan dengan jenis-jenis kelengkapan atau persyaratan teknis dalam pengurusan proses penyelesaian pelayanan. perizinan. Mal Pelayanan Publik Kota Bekasi harus selalu bisa dapat terhubung dengan jelas atau terjadi sinkronisasi yang baik dalam sistem online ini antara Mal Pelayanan Publik dengan Dinas-dinas terkait. Hal ini diperlukan agar di kemudian hari dapat meminimalisir terjadinya kesalahan datadata dari masyarakat sehingga tidak terjadi kekeliruan yang dapat memperhambat.

\section{SIMPULAN}

Berdasarkan hasil penelitian yang dilakukan penulis tentang Implementasi Kebijakan Mal Pelayanan Publik di Kota Bekasi, maka penulis menarik simpulan dalam penelitian ini adalah sebagai berikut.

1. Implementasi Kebijakan di Mal Pelayanan DPMPTSP di Kota Bekasi khususunya Mal Pelayanan Publik belum optimal. Belum optimalnya pelayanan publik disebabkan oleh kelemahan dalam dimensi produktivitas, linearitas, dan efisiensi.

2. Faktor-faktor yang memengaruhi proses pelayanan pada Mal Pelayanan Publik Kota Bekasi adalah belum konsistennya para implementor terhadap isi 
kebijakan, belum optimal interaksi jejaring kerja terkait dengan kerja sama antara Mal Pelayanan Publik dengan instansi teknis terkait terlihat kurangnya sinergitas dan koordinasi sehingga SOP belum optimal dalam pemberian pelayanan. Upaya yang dilakukan oleh DPMPTSP Kota Bekasi khususnya Mal Pelayanan Publik untuk meningkatkan Implementasi Kebijakan Pelayanan Publik adalah penambahan anggaran untuk menunjang program pelayanan pada Mal Pelayanan Publik, mengembangkan kualitas sumber daya manusia terkait kompetensi melalui kegiatan pendidikan dan pelatihan serta bimbingan teknis. Mengembangkan sistem online yang juga menjadi prioritas DPMPTSP Kota Bekasi dalam meningkatkan kualitas pelayanan Publik, dengan begitu masyarakat akan lebih mudah mengakses dan mengawasi langsung proses Pelayanan di Kota Bekasi.

\section{SARAN}

Beberapa saran yang akan diberikan oleh penulis kepada Dinas Penanaman Modal dan Pelayanan Terpadu Satu Pintu Kota Bekasi khususnya Mal Pelayanan Publik adalah sebagai berikut.

1. Peningkatan Implementasi Kebijakan Mal Pelayanan Publik seharusnya memperhatikan tiga dimensi yang meliputi produktivitas, linearitas, dan efisiensi sebagai tolak ukur dalam meningkatkan pelaksanaan pelayanan kepada masyarakat.

2. Pemerintah Kota Bekasi dalam hal ini DPMPTSP Kota Bekasi harus menyiapkan anggaran yang dibutuhkan secara berkelanjutan dan simultan dalam melaksanakan program pada Mal Pelayanan Publik supaya pelayanan yang cepat, tepat, transparan, dan terjangkau dapat dirasakan masyarakat.

3. Lebih menyempurnakan lagi program pelayanan yang berbasis online, sehingga masyarakat dapat dengan mudah mengakses informasi terkait pelayaanan pada Mal Pelayanan Publik Kota Bekasi dan meningkatkan kemampuan pegawai dalam bidang IT dalam rangka mengikuti perkembangan 4.0.

\section{DAFTAR PUSTAKA}

Achmad, Mansyur. 2011. Teori-Teori Muktahir Administrasi Publik. Jakarta: Rangkang Education

Agustino, Leo. 2014. Dasar-Dasar Kebijakan Publik. Bandung: Alfabeta.

Arikunto, Suharsimi. 2010. Prosedur Penelitian Suatu Pendekatan Praktis. Jakarta: Rineka Cipta

Bhattacherjee, Anol. 2012. Social Science Research: Principles, Methods, And Practices. USA:

Creative Commons Atribusi-BY

Bogdan, R.C, \& Biklen, S.K. 2007. Qualitative research for education: An introduction to theories and methods (5th ed.). Boston: Pearson Education

Calderon, Jose F, Expectation C Gonzales. 1993. Method of Research and Thesis Writing. Madaluyung City. National Book Store.

Creswell, Jhon W. 2013. Research Design Pendekatan Kualitatif, Kuantitatifdan Mixed. Yogyakarta: Pustaka Pelajar.

Dwiyanto, Agus. 2008. Mewujudkan Good Governance Melalui Pelayanan Publik. Yogyakarta: Gajah Mada University Press

Giroth, Lexie, M. 2005. Pamong Praja Kibernologi dan Metakontrologi, Jatinagor: CV Indra Prahasta. 
Gibson, 1992. Organisasi dan Manajemen.

Perilaku, Struktur, Proses. Edisi Keempat. Jakarta: Airlangga

Given, M. Lisa. 2008. The Sage Encyclopedia of Qualitative Research Methods. Charles Sturt University, Australia.

Hamdi, Muchlis. 2014. Kebijakan Publik Proses, Analisis, dan Partisipasi. Bogor: PT Ghalia Indonesia

Ibrahim, Amin. 2008. Teori dan Konsep Pelayanan Publik Serta Implementasinya. Bandung: CV. Mandar Maju

Islamy, M Irfan. 2007. Prinsip-Prinsip Perumusan Kebijakan Negara. Jakarta: Bumi Aksara

Luankali, Bernadus. 2007. Analisis Kebijakan Publik dalam Proses Pengambilan

Keputusan. Jakarta: Amelia Press

Lukman, Sampara. 2000. Manajemen Kualitas Pelayanan. Jakarta: STIA LAN-RI.

Merriam, S.B. 2001. Qualitative Research and Case Study Applications In Education. San Fransisco: Jossey-Bass

Moenir. 2001. Manajemen Pelayanan Umum di Indonesia. Jakarta: PT.Bumi Aksara

Moleong, J. Lexy., 2014. Metodologi Penelitian Kualitatif. Edisi Revisi. Bandung: PT. Remaja Rosdakarya.

Mulyadi, Mohammad. 2014. Metode Penelitian Praktis Kuantitatif dan Kualitatif. Jakarta: Publica Institute.

Napitupulu, Parmin. 2007. Pelayanan Publik dan Customer Satisfaction. Bandung: PT. Alumni

Neuman, W Laurence. 2006. Social Research Methods. United States o America: Allyn and Bucon.

Ndraha, Taliziduhu. 2005. Kybernology (Imu Pemerintahan Baru) Jilid 1 \& 2. Jakarta: Rineka Cipta

Purwanto, Erwan Agus dan Dyah Ratih Sulistyastuti. 2012. Implementasi Kebijakan Publik Konsep dan Aplikasinya di Indonesia. Yogyakarta: Gava Media

Rasyid, Ryaas. 2007. Makna Pemerintahan Tinjauan dari Segi Etika dan Kepemimpinan. Jakarta: Mutiara Sumber Widya

Ratminto \& Winarsih, Atik Septi. 2010. Manajemen Pelayanan. Yogyakarta: Pustaka Pelajar.

Ridwan, Juniarso. 2009. Hukum Administrasi Negara dan Kebijakan Pelayanan Publik. Bandung: Nuansa

Setya Retnami. 2001. Sistem Pemerintahan Daerah di Indonesia, Jakarta: Kantor Menteri Negara Otonomi Daerah Republik Indonesia,

Silalahi, Ulber. 2012. Metode Penelitian Sosial. Bandung: PT. Refika Aditama.

Sinambela, Lijan Poltak. 2014. Reformasi Pelayanan Publik. Jakarta: Bumi Aksara

Soehartono, Irawan. 2011. Metode Penelitian Sosial. Bandung: PT. Remaja Rosdakarya.

Sugiyono. 2013. Metode Penelitian Kuantitatif Kualitatif dan $R \& D$. Bandung: Alfabeta.

Syafri, Wirman dan Setyoko, Israwan. 2010. Implementasi Kebijakan Publik dan Etika Profesi Pamong Praja. Bandung: Alqaprint Jatinangor

Tjiptono dan Gregorius, Chandra. 2011. Service, Quality dan Satisfaction. Yogyakarta: Andi Ofset.

Triguno. 1999. Budaya Kerja: Menciptakan Lingkungan Kerja yang Kondusif untuk Meningkatkan Produktivitas Kerja, Jakarta:Golden Edvon Press

Wahab, Solichin Abdul. 2012. Analisis Kebijakan: dari Formulasi ke Kebijakan Negara. Jakarta: Bumi Aksara

Wibawa, Purbokusumo. 1994. Evaluasi Kebijakan Publik. Jakarta: PTRaja Grafindo Persada 
Widodo, Joko. 2009. Konsep Aplikasi Analisis Proses KebijakanPublik. Malang: Bayu Media Publishing.

Winarno, Budi. 2012. Kebijakan Publik. Teori dan Proses (Edisi Revisi).Yogyakarta: Media Pressindo. 